International Journal of Instruction e-ISSN: 1308-1470 • www.e-iji.net

Article submission code: 20200203113402

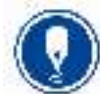

January $2021 \bullet$ Vol.14, No.1

p-ISSN: 1694-609X

pp. 673-690

Received: 03/02/2019

Revision: 21/07/2020
Accepted: 13/08/2020

OnlineFirst:10/11/2020

\title{
Arab Postgraduates' Readiness towards and Effectiveness of Utilizing Web 2.0 in Language Learning
}

'Mohamed noor' Mahmoud Aref Jarrah

Lecturer, College of Sciences and Humanities, Prince Sattam Bin Abdulaziz University, Saudi Arabia,abunoor546@gmail.com

\section{Ali Abbas Falah Alzubi}

Asst. Prof., correspondent author, Faculty of languages, Najran University, Saudi Arabia, aliyarmouk2004@gmail.com

The study aimed to investigate the Arab English language learners' readiness towards and effectiveness of using Web 2.0 applications in language learning process at a university in Malaysia. Using a quantitative research design, 50 Arab postgraduates responded to a questionnaire about their readiness towards and effectiveness of Web 2.0 applications in enhancing their English learning process in relation to genders and level of study. The findings showed that learners' readiness towards and effectiveness of using Web 2.0 applications in language learning was moderate. In addition, it was revealed that YouTube, Facebook, and Skype gained the highest mean scores of all Web 2.0 applications in language learning process. Genders and level of study proved to be significant in relation to the effectiveness of Web 2.0 in language learning process. It is recommended that training on Internet and integration skills be proved to learners of a new language to allow them more reliable resources into their learning process. Further research on the practice and attitudes of educators in using Web 2.0 technologies for teaching English language is suggested.

Keywords: Arab postgraduates, perceived usefulness, language learning process, readiness, Web 2.0

\section{INTRODUCTION}

Advancements in Information and Communication Technology (ICT) have influenced various aspects of life and language education is no exception. Nowadays, there are more English teachers and lecturers adopting Internet or other ICT products excessively to help them in their classroom as well as to meet the objectives and learning outcomes (Gilakjani, 2017; Shyamlee \& Phil, 2012). The Internet world has entered a new era called Web 2.0 that is believed to bring more benefits in language teaching and learning. Web 2.0 is popular among young people and has been an avenue for educational issues among teachers, lecturers, researchers, and learners (Assksoy, 2018; Ayres, 2002; Eneau

Citation: Jarrah, M. A. \& Alzubi, A. A. F. (2021). Arab Postgraduates' Readiness towards and Effectiveness of Utilizing Web 2.0 in Language Learning. International Journal of Instruction, 14(1), 673-690. https://doi.org/10.29333/iji.2021.14141a 
\& Develotte, 2012; Lee, 2005). Web 2.0 can also promote collaboration among learners or students, offer educators a set of tools to support form of learning, stimulate a form of intelligence, develop the learners' confidence, and strengthen the fundamentals of learning based on the commentary Technology Enhanced Learning Phase of the Teaching and Learning Research Programme (TLRP-TEL) in 2008.

Students must be ready to embrace this Web 2.0 growth in their learning process. A good number of Arab postgraduates from different backgrounds study at Malaysian universities and in order to understand their readiness and perceived usefulness towards the use of Web 2.0 tools in their language learning process where they are expected to be more motivated and encouraged, so that the learning outcome can be achieved successfully, this study is significant in investigating the degree of the Arab postgraduate learners' readiness of utilization of Web 2.0 in language learning process. The study also functions to lend support to the literature by contributing to the characteristics of new innovations on academia in embracing technologies in their learning process as well as recognizing the shortcomings that impede academic students from using Web 2.0 technologies in a broader way, thereby facilitating educational policy makers to assess the electronic media and wade through the obstacles. Therefore, this study aims to investigate perceived usefulness and effectiveness towards utilization of Web 2.0 in English learning process in terms of gender and level of study. It will also investigate the kinds of Web 2.0 tools employed in English learning process among Arab learners at a Malaysian university.

\section{REVIEW OF LITERATURE}

\section{Web 2.0}

Web 2.0, first popularized by O'Reilly and Dale Dougherty in 2004, refers to the second generation of web-based services emphasizing online collaboration, creating, and sharing (Collis \& Moonen, 2008). According to ERSC society (2008), Web 2.0 assists users to work together and share knowledge online; it helps the online users collaborate with each other and disseminate the developed contents. Furthermore, Web 2.0 makes the users to turn out to be producers of information. Web 2.0 consists of websites and web applications that enable users to be involved and disseminate their contents through Blogs, Micro blogging sites, Mash-ups, Podcasts, Social networking, Social Media, and Wikis. The special aspect of Web 2.0 is that, there is no need for users to install the software, rather they have just to visit the web and use the content present there (Rosen, 2006).

\section{English Language Learning through Web 2.0}

Web 2.0 features higher educational perspective due to the fact that learners do not require exclusive training to use it. When using Web 2.0, as soon as an instructor introduces the activity, students can proceed on their own (Shihab, 2008). The teaching staff can keep the track of their students' progress online. The students can instantly send feedback. Moreover, Web 2.0 applications such as Wikis, Blogs, and YouTube enable users to take accountability of what they write and post. Writing and posting for visitors can support to enhance their English language, since the style and content of the 
contribution demand the members more significantly look at what they write (Grosseck, 2009). The stress of writing for a global audience makes users to be more mindful about what and how they write. Consequently, Web 2.0 applications can be good avenues for EFL learners who can enjoy more exposure to the target language and hence, can communicate and interact with others more appropriately (Almekhalfy \& Alzubi, 2016). For example, blogs have been applied in different ways for various educational purposes, including learning English language. Using blogs, teachers could develop, modify, or remove their lecture notes (Johnson, 2004); students can upload images, songs, and videos online with links to their weblogs (Campbell, 2004); learners can work in a collaborative environment to promote their language learning process (Kleanthous \& Cardoso, 2016).

Twitter does have some fascinating prospectives for EFL education in general and writing skill in particular. It makes users to be succinct and to focus on the point. This is a significant language capability to develop, and projects on Twitter enable students to work on the brief writing skill. Interestingly, Twitter might basically be beneficial for teaching grammar. A number of comments made on Twitter and Facebook usually compresses and neglects grammatical rules; furthermore, creating a distinctive type of Twitter shorthand, makes messages actually complicated for the inexperienced users to understand (Paul \& Friginal, 2019). For vocabulary building, students can construct English terms by posting a new word (selected by themselves or allocated by others) with model sentences (either their own or one from a dictionary) each day, class, week, etc. If there is space on the post, they can post the meaning of the word, alternatives, opposites, and homonyms. This can be performed every day or every week, and the teacher (or students) might generate a vocabulary test, depending on posts of others. Students can also answer to the word with their own posts of example sentences, preferably their own examples. Sites like Chitter.TV (http://chitter.tv) would benefit learners to listen and practice more, thus improve their listening skills. Twitter has been proved to facilitate the learners' language learning experience in terms of communication and social interaction (Taskiran, Gumusoglu, \& Aydin, 2018) and to discover new vocabulary and communicating in English (Alshabeb \& Almaqrn, 2018).

YouTube has been significantly used by teachers and students as an educational tool, for almost everything, from newsworthy events from worldwide to descriptive videos used to teach students within an English as a Second Language (ESL) course to improve the learners' vocabulary, diction, pronunciations, voice intonation and so on as it provides genuine illustrations of everyday English, used by day-to-day people and promotion a learning style to more independent and student-centered. The integration of YouTube has been found to be a powerful effect on the vocabulary recognition, comprehension and retention of the target vocabulary (Kabooha \& Elyas, 2018). To illustrate, students can speak about their dairies in front of a web camera for a short time (Vilogging). They can view and assess their recorded statements before deciding to post it, and then watch and listen to the feedback of their classmates or teacher related to the vlog. Note-taking and summarizing can be practiced through YouTube where students can listen to lectures on different subjects, taking notes on the main points and important details, verbally check and expand their notes with an associate, again listening for further 
expanding their notes, and then summarizing their notes. The students can later check out the transcript of the clip, and compare their summaries with the ones from their friends and educators. Short video clips in EFL classrooms were found to be more motivating and interactive to students throughout the learning process (Kabooha, 2016).

Wikis, enable people to easily generate and modify the contents of web pages. According to Leuf and Cunningham (2001), Wiki is defined as an easily extensible selection of interlinked web pages which facilitate the organization and change of information; every single page can be quickly edited by the users with a web browser client. Few other studies have investigated the advantages of wikis; students have a lot of advantages in utilizing wikis for collaborative learning. A lot of students have recognized that wikis are entertaining and fascinating resources of sharing knowledge (Chao \& Lo, 2009; Ducate, Anderson, \& Moreno, 2011; Lee, 2010; Lundin, 2008; Zorko, 2009), and also encourage for learning (Chao \& Lo, 2009; Lee, 2010; Woo, Chu, Ho, \& Li, 2011; Zorko, 2009). According to Lee (2010) wikis have enhanced students' determination to be self-controlled because of the peer relationship and personal obligation in the wiki-based collaborative work. Furthermore, few students have stated that, collaborative writing and associated comments in wikis facilitated them to write improved articles, with regards to content, structure, and grammar (Chao \& Lo, 2009; Elola \& Oskoz, 2010; Lee, 2010; Woo et al., 2011). Furthermore, wiki-based collaborative writing has empowered students to scaffold each other in content development, and obtain more viewpoints of specific subjects (Kost, 2011; Li \& Zhu, 2011; Lundin, 2008). For example, Lundin (2008) stated that, specifically, students have valued the multifaceted and mutuality of contributions along with accumulated outcome in the wiki environment. Furthermore, Zorko (2009) and Lin and Yang (2011) claimed that students preferred the instant feedbacks from teachers provided through wikis, which significantly triggered their collaborative work.

Skype that offers telephone service by means of Voice over Internet Protocol (VoIP), enables users to communicate with their friends and relatives across the globe (GodwinJones, 2006). The audio component enables the development of phonic skills, while the visual component facilitates the students to "read" the body language and facial expressions that play a crucial role in non-verbal communication.

Podcasts, previously known as audio blogs, comprise audio recordings, generally in MP3 format, of discussions, interviews, and lectures that can be played either on a desktop computer or on a number of portable MP3 devices (Anderson, 2007). Podcasts are effective tools that can assist language learners to listen to lecturers posted on the web by native speakers, or even enable students to practice their speaking skills by recording their own podcasts (Lee, 2009; Viswanathan, 2008). Students can also improve their pronunciation of words and phrases for foreign languages (Ormond, 2008). In addition, students can to create their assignments by recording an oral presentation (Cundell, 2008). Podcasts are seen as a means for more understanding of materials (Frenando, 2008), feedback and assessment (Wu, Hsu, Teng \& Wu, 2010), and a way of depiction (Ducate \& Lomicka, 2009). 
Tags are free-form labels, selected by the user, and not picked from governed vocabulary (Godwin-Jones, 2006). These labels have been selected depending on the enclosed content. Tags facilitate the function of classifying information (Anderson, 2007) which consequently helps search engines rapidly and easily get the contents (Henzinger, Motwani, \& Silverstein, 2002). Tags are now accessible in other Web2.0 applications like social bookmarking, blogs and photo sharing websites. This functionality can be generally employed in ESL classes which aims at providing the technique of reviewing, enabling students to see the benefit of this skill in their daily lives. Tags also help to develop the experience of a community in a classroom, help students collectively build a tag cloud. A tag cloud is a group of tags arranged as maps which allow re-visualization of others' work (Alexander, 2006). These tag clouds also enable students to learn from each other by being introduced to others' tag.

Social bookmarking was first launched by Joshua Schacter through del.icio.us website (Alexander, 2006). Social bookmarking allows users to favourite websites online; consequently, offering the capability to access these bookmarks, whenever and from anyplace with Internet access. It also has the possibilities for users to classify, rate, and comment on the resources (Abbitt, 2009). Social bookmarking is usually utilized as an online reading package for the class which provides students with essential links for reading online by downloading articles and documents which are supposed to be learnt in class (Franklin \& Harmelen, 2007). Furthermore, as social bookmarks' application providers provide the ability to know who has bookmarked and what has been bookmarked (Coutinbo \& Junior, 2008), and hence, students can generate a social community amongst each other by recognizing those who have common interests (Franklin \& Harmelen, 2007) which will consequently support to create a more relaxed learning environment for students in their language class, and minimizing their restricting filter.

Multi-media sharing provides the capability of posting, sharing, searching, ranking and observing various kinds of multimedia, including, audio, videos, and images (Anderson, 2007; Franklin \& Harmelen, 2007). Educators can make use of a Flickr account and employ the attributes that are available to provide students with details, class interactions, and collaborative comments (Franklin \& Harmelen, 2007); videos enable students to respond to something more active (Canning-Wilson, 2000; Cardine, 2008).

Technology Acceptance Model (TAM) introduced by Davis, Bagozzi, and Warshaw TAM (1989) has explained the phenomena of acceptance of computer technology, in terms of various contexts of settings. Based on TAM, the perceptions of users towards using new technologies can be predicted. TAM looks at the attitudes of the user's perception in terms of usefulness of the computer technology, their attitude towards computer, the reasons for using technology, and the applications of the technology, as illustrated in Figure 1. 


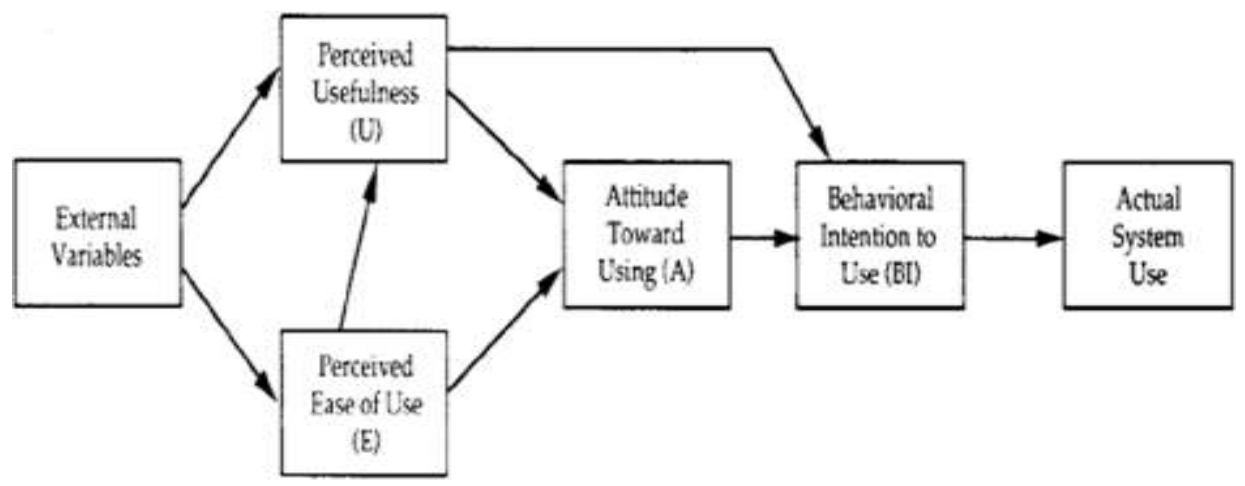

Figure 1. Technology acceptance model (TAM) introduced by davis, bagozzi, and warshaw

It is believed that when users perceive the usefulness and ease of use of the Web 2.0 applications, their attitudes towards using Web 2.0 will become the internal driving factors that motivate them to increase their level of using Web 2.0 applications. Subsequently, this will affect the process of language learning. Particularly, if language learning process is integrated with Web 2.0 in classrooms. In the other words, the high and low level skills of using Web 2.0 might further impact their level of interest in the language learning process.

In the Arab world, there is a lack of studies on evaluating the adoption, usage, and impact of Web 2.0 in the contexts of learning, such as the micro-blogging application (Twitter) (Al-Hawari, 2009; Al-Khalifa, 2010). A number of studies have been conducted in terms of using computer technologies in education in the Arab world (AlHawari, 2009; Bell, 2009). The majority of prior studies have reviewed the general use of computers and internet usage (e.g. Allehaibi, 2001; Al-Oteawi, 2002; Al-Wehaibi, Al-Wabil, Alshawi, \& Alshankity, 2008). Therefore, utilizing TAM by Davis et al. (1989) as a conceptual framework for the study, this study will explore the Arab English language learners' readiness towards and effectiveness of using web 2.0 applications in language learning process at a Malaysian university in relation to genders and level of study in Malaysia.

\section{METHOD}

This study followed the quantitative research design to collect data through a crosssectional questionnaire to answer the study research questions. Based on the theoretical framework of the study, the evaluation of using Web 2.0 technology by Arab postgraduates in terms of perceived usefulness, effectiveness of Web 2.0 tools in English language learning process are examined.

Malaysian universities have attracted a lot of international students pursuing their undergraduate and graduate studies from different parts of the world such as from Africa countries, Arab countries, and other Asia countries. The students from those countries 
have their own characteristics as well as barriers in dealing with their learning process in technology-enhanced environments (Alajmi, 2011; Al Shlowiy, 2016; Najeeb, Maros \& Nor, 2012). In the Arab world, the adoption of technology in education is still below expectation. On the one hand, learners manage to achieve their learning goals by attending classes, participating and involving in any learning activities, and engaging themselves with all tasks lecturers give. On the other hand, lecturers involve technology or more specifically Internet in their teaching-learning activities, learners who are encouraged to use technology in learning need to enhance their learning skills in technology-based environments regardless various backgrounds, cultures, and customs as well as the situation of the home country. However, very little is known about the learners' attitudes, readiness towards, and effectiveness of utilization of Web 2.0 coming from various backgrounds, cultures, and customs. Therefore, this study attempts to answer the following research questions:

1. What is perceived usefulness of Web 2.0 in English language learning process among Arab learners at Universiti Kebangsaan Malaysia (UKM)?

2. How effective is the use of Web 2.0 in enhancing the Arab students' English learning process in terms of gender and level of study?

3. What are the kinds of Web 2.0 tools that employed in English language learning process at UKM?

\section{Sample of the Study}

For the aim of this study, an appropriate sampling was adopted as the respondents are (50) postgraduate (Arab) students (male $=39$, female $=11$ ) who are studying in Universiti Kebangsaan Malaysia (UKM) from five Arab nationalities. This study examines various variables (1) perceived usefulness of Web 2.0 among Arab learners towards the utilization of Web 2.0 in the English learning process at UKM in terms of genders and level of study, (2) the effectiveness of Web 2.0 in enhancing the Arab students' English learning progress in terms of genders and level of study, (3) the tools of Web 2.0 employed in English learning process at UKM. All the 50 respondents were asked to answer the questionnaire. Criteria were set in the selection of the study sample. Firstly, the important demands for the sample were that they required being Arab students. Secondly, the sample was made on the basis of obtainability most of the time and the implementation of the research instruments can be achieved according to the appropriateness (Creswell, 1994).

\section{Study Instruments}

A close-ended questionnaire was used in this study. The questionnaire was divided into four sections. The first section (Five items) identified learners' profile and personal information such as gender, level of study, and nationality. The second section (10 items) of the questionnaire identified the tools of Web 2.0 that employed in the English language learning process and is adopted from Alajmi (2011) and it answered the kinds of Web 2.0 tools that employed in English language learning process at UKM, while the third section (16 items) investigated perceived usefulness of Web 2.0 among Arab 
learners towards utilization of Web 2.0 in English learning process at UKM. The final section (nine items) measured the effectiveness of Web 2.0 in language learning process. The third and final sections of the questionnaire, with some modifications, were based on Arshad, Tan, \& Hashim's (2012) and Vandewaetere and Desmet's (2009) questionnaire which was used to validate and measure the attitudes of learners towards Computer-assisted language learning (CALL) that have the similar features with Web 2.0 as both of them use computer as the media for learning and to meet the objectives of the study.

The questionnaire used Likert scale which is rated from 1-4. The questionnaire has four sections. Likert scale for section B were 1-Never use, 2-Rarely use, 3-Sometimes, and 4Regularly. Likert scale for sections $\mathrm{C}$ and D were 1- strongly disagree, 2- disagree, 3agree, and 4- strongly agree. The questionnaire was distributed to the learners at UKM during their actual time of study by the researchers. Reliability was measured to ensure suitability to the population and what it needs to measure. The questionnaire was piloted to a number of students other than those who participated in the main study. Based on the results of analysis in the table below (Table 1), the values showed that the questionnaire was reliable. Students' perceived usefulness of Web 2.0 in the English learning process scored $(\alpha=0.814)$ and the effectiveness of Web 2.0 in language learning process $(\mathrm{a}=0.871)$.

Table 1

Reliability statistics

\begin{tabular}{lll}
\hline Variable & Cronbach's Alpha $(\alpha)$ & No of items \\
\hline $\begin{array}{l}\text { Students' perceived usefulness of Web 2.0 in English } \\
\text { learning process }\end{array}$ & .814 & 16 \\
\hline Effectiveness of Web 2.0 in language learning process & .871 & 9 \\
\hline
\end{tabular}

\section{RESULTS}

\section{Descriptive Analysis}

\section{Respondents' characteristics}

A total of 50 respondents participated for the present study; 39 male participants (79\%) and 11 female participants (22\%). As for nationality, 27 Jordanians (54\%), 8 Yemenis (16\%), seven Iraqis (14\%), five Libyans (10\%), and three Palestinians $(6 \%)$ participated in the study. Concerning the years of study, most of participants were two years $(34 \%)$, while $22 \%$ were only a year. $16 \%$ were 3 years, $12 \%$ five years, $10 \%$ four years and only $6 \%$ six years. The highest number of the respondents $(\mathrm{n}=30)$ was $\mathrm{PhD}$ students $(60 \%)$ and the remaining $(n=20) 40 \%$ were Master's degree students. Regarding years in Malaysia, the majority of responders had studied for two years $(38 \%)$, while some studied only a year (24\%), $20 \%$ studied for three years and $18 \%$ for four years. 


\section{Students' perceived usefulness towards the Utilization of Web 2.0 in the language learning process}

Table 2. represents the mean and standard deviation $(\mathrm{M}( \pm \mathrm{SD}))$ of all items in the students' readiness towards utilization of Web 2.0 in language learning process'. There are 16 items in this variable.

Table 2

Students' perceived usefulness towards the utilization of Web 2.0 in the language learning process

\begin{tabular}{|c|c|c|c|}
\hline & Item & Mean & SD \\
\hline 1. & I can study language well with Web 2.0 technologies & 3.24 & .846 \\
\hline 2. & $\begin{array}{l}\text { My speed of learning to work with Web } 2.0 \text { technologies is higher than } \\
\text { others }\end{array}$ & 3.22 & .887 \\
\hline 3. & I like to use Web 2.0 technologies for language learning & 3.14 & .808 \\
\hline 4. & Language can be learned faster by using Web 2.0 technologies & 3.36 & .875 \\
\hline 5. & $\begin{array}{l}\text { Learning a foreign language through Web } 2.0 \text { technologies is better than } \\
\text { oral practice. }\end{array}$ & 2.42 & .906 \\
\hline 6. & $\begin{array}{l}\text { Language learning by using Web } 2.0 \text { technologies is less adequate as the } \\
\text { traditional learning }\end{array}$ & 2.76 & .847 \\
\hline 7. & $\begin{array}{l}\text { Students who use Web } 2.0 \text { for language learning are less than those who } \\
\text { learn language through traditional methods. }\end{array}$ & 2.86 & .881 \\
\hline 8. & $\begin{array}{l}\text { Web } 2.0 \text { technologies are good as the traditional language learning } \\
\text { methods }\end{array}$ & 3.22 & .996 \\
\hline 9. & $\begin{array}{l}\text { Web } 2.0 \text { technologies are good enough to be used alone for language } \\
\text { learning. }\end{array}$ & 2.70 & 1.165 \\
\hline 10. & $\begin{array}{l}\text { Web } 2.0 \text { technologies are more stress-free than traditional methods of } \\
\text { language learning. }\end{array}$ & 3.02 & .845 \\
\hline 11. & $\begin{array}{l}\text { Using Web } 2.0 \text { technologies can enhance my chances to learn a foreign } \\
\text { language. }\end{array}$ & 3.52 & .814 \\
\hline 12. & $\begin{array}{l}\text { The content of language learning materials of Web } 2.0 \text { technologies is } \\
\text { excellent. }\end{array}$ & 3.22 & .815 \\
\hline 13. & $\begin{array}{l}\text { I feel more comfortable while interacting with others in foreign language } \\
\text { via Web } 2.0 \text { technologies. }\end{array}$ & 3.16 & .792 \\
\hline 14. & I am aware that I can learn English language using Web 2.0 technologies. & 3.38 & .779 \\
\hline 15. & Web 2.0 technologies functions are easy to use for language learning & 3.48 & .762 \\
\hline & I intend to use Web 2.0 technologies to ir & 3.46 & .813 \\
\hline & Overall & 3.135 & 0.477 \\
\hline
\end{tabular}

As Table 2. depicts, the highest mean score was 'Web 2.0 technologies functions are easy to use for language learning', $(3.48( \pm 0.762))$ and the lowest was 'Learning a foreign language through Web 2.0 technologies is better than oral practice', $(2.42$ ( \pm $0.906))$. The overall mean score for this variable was $(3.135( \pm 0.447))$.

\section{The Effectiveness of Web 2.0 in Language Learning Process}

Table 3. represents the mean and standard deviation $(\mathrm{M}( \pm \mathrm{SD}))$ of all the items $(10$ items) of the effectiveness of Web 2.0 in language learning process. 
Table 3

Effectiveness of Web 2.0 in language learning process

\begin{tabular}{lcc}
\hline Item & Mean & SD \\
\hline 1- Web 2.0 technologies develop my reading skills & 3.28 & .757 \\
\hline 2- Web 2.0 technologies develop my listening skills & 3.12 & .848 \\
\hline 3- Web 2.0 technologies develop my writing skills & 3.18 & .661 \\
\hline 4- Web 2.0 technologies develop my speaking skills & 3.12 & .799 \\
\hline 5- Web 2.0 technologies develop my grammar & 2.80 & .948 \\
\hline 6- Web 2.0 technologies develop my vocabulary knowledge & 3.30 & .707 \\
\hline 7- Web 2.0 technologies help me to pass my foreign language tests & 2.92 & .899 \\
\hline 8- Web 2.0 technologies are useful tool for me to practice my skills in English language & 3.18 & .746 \\
\hline 9- I believe that using Web 2.0 technologies can enhance my English competency level & 3.22 & .764 \\
\hline Overall & 3.118 & .556 \\
\hline
\end{tabular}

As shown in Table 3, the overall mean score for the effectiveness of Web 2.0 in language learning process was $(3.118( \pm 0.556))$. The highest mean score was 'Web 2.0 technologies develop my vocabulary knowledge', $(3.30( \pm 0.707))$ and the lowest was 'Web 2.0 technologies develop my grammar', $(2.80( \pm 0.948))$.

\section{The use of Web 2.0 applications}

The use of Web 2.0 applications was analyzed for the mean and standard deviation (M $( \pm \mathrm{SD}))$. The following table shows the scores of 10 Web 2.0 applications.

Table 4

The use of Web 2.0 applications

\begin{tabular}{lll}
\hline Web 2.0 applications & Mean & SD \\
\hline Facebook & 3.62 & .725 \\
\hline Twitter & 2.00 & 1.178 \\
\hline MySpace & 1.48 & .886 \\
\hline YouTube & 3.66 & .658 \\
\hline Flickr & 1.38 & .855 \\
\hline Skype & 3.28 & .927 \\
\hline MSN Messenger & 2.40 & 1.161 \\
\hline De.licio.us & 1.14 & .535 \\
\hline Blogs & 1.30 & .544 \\
\hline Wikipedia & 3.22 & .975 \\
\hline
\end{tabular}

The scores can be categorized into three categories: high use, mid use, and low use. In the high use category are 'YouTube' $(3.66( \pm 0.658))$, followed by 'Facebook' $(3.62( \pm$ $0.725)$, 'Skype' $(3.28( \pm 0.927))$, 'Wikipedia' $(3.22( \pm 0.95))$. In the mid category fall 'MSN Messenger' $(2.40( \pm 1.161))$, and 'Twitter' $(2.0( \pm 1.178))$. In the low use category come 'MySpace' (1.48 ( \pm 0.886)), 'Flickr' (1.38 ( \pm 0.855$))$, 'Blog' $(1.30( \pm 0.544))$ and 'Delicious' $(1.14( \pm 0.535))$.

\section{Inferential Statistics}

Correlation analysis was used to describe the strength and direction of the linear relationship between the usage of Web 2.0 tools in English language learning process 
and genders and level of study at UKM. Using Pearson's correlation, the results showed a significant relationship between the perceived usefulness of Web 2.0 among Arab learners towards the utilization of Web 2.0 in the English learning process at UKM and the effectiveness of Web 2.0 in Language Learning Process $(r=0.716, p<0.05)$.

Independent samples t-test was used to test to find out the differences of students' perceived usefulness towards the utilization of Web 2.0 in the language learning process between male (39) and female (11) students. Homogeneity of variance was determined by Levene's test for equality of variances. It was reported that $F=5.923$ and the significance level for Levene's test is $p<0.05$, therefore, as the variances was significantly different, equal variances not assumed was appropriate to used. The result showed that there is a significant difference in the scores of perceived usefulness between males $(\mathrm{M}=3.079, \mathrm{SD}=0.483)$ and females $(\mathrm{M}=3.35, \mathrm{SD}=0.194 ; \mathrm{t}(48)=-$ $2.648, p=0.011,(p<0.05)$. However, the effectiveness of Web 2.0 in language learning process with regard to the genders of students also proved to be insignificant $(\mathrm{M}=3.172, \mathrm{SD}=0.392 ; \mathrm{t}(48)=-0.354, \mathrm{p}=0.725,(\mathrm{p}>0.05)$.

The results of Independent samples t-test analysis also showed there is no significant difference in perceived usefulness for Master's Degree $(M=3.28, S D=0.443)$ and $\mathrm{PhD}$ $(M=3.073, S D=0.446 ; t(48)=1.208, p=0.233$, $(p>0.05)$ after having tested the homogeneity of variances which proved to be equal $(F=0.158, p>0.05)$. Effectiveness of Web 2.0 in language learning process with regard to the level of the learners' study also proved to be insignificant $((\mathrm{M}=3.183, \mathrm{SD}=0.523)$ and $\mathrm{PhD}(\mathrm{M}=3.074, \mathrm{SD}=$ $0.598 ; \mathrm{t}(48)=0.665, \mathrm{p}=0.510,(\mathrm{p}>0.05)$.

\section{FINDINGS AND DISCUSSION}

This study investigated the use of Web 2.0 tools in English Language learning among Arab students at UKM. It was revealed that students' perceived usefulness towards utilization and effectiveness of using Web 2.0 in English language process was moderate. Arab students mostly preferred the use of YouTube, Facebook, and Skype for learning English language. It was also shown that females had more perceived usefulness and effectiveness of Web 2.0 in language learning process than males. Furthermore, master's students showed more perceived usefulness and effectiveness towards using Web 2.0 in language learning process than PhD students.

The findings on the moderateness of usefulness towards utilization of Web 2.0 in English language process reported in this study are in line with those findings by Aydin (2017) who found EFL learners moderately perceived that Facebook might constitute a place to share and offer language resources and multimedia materials as well as it support e-learning, discussions, individual and collaborative learning. The findings are also similar to Taskiran, Gumusoglu, and Aydin's (2018) findings which revealed positive opinions on using Web 2.0 (Twitter) in facilitating Turkish learners' language learning experience in terms of communication and social interaction. In addition, Kung (2018) confirmed these findings when reported that learners perceived their writing instruction through blog-assisted language learning positively. Furthermore, the findings are in accordance with those by Kleanthous and Cardoso (2016) who showed that blogs were perceived as motivating and fun tools to promote language learning within a 
collaborative environment in their writing, speaking and reading skills. Finally, Kitchakarn (2016) found that perceived ease of use had positive relationships between perceived usefulness of Facebook and attitudes towards doing the activities in Facebook.

However, the findings on the moderateness of perceived usefulness towards the use of Web 2.0 in English language learning are not consistent with some previous research such as, Alajmi (2011), and Zakaria, Watson, and Edwards (2010) who showed students had significant readiness with certain Web 2.0 tools in English language learning process. Also, the findings are not in agreement with Burhanna, Seeholzer, and Salem (2009) who found that many participants demonstrated a limited readiness of Web 2.0 applications. In addition, this study reported moderate usefulness of Web 2.0 in language learning process whereas Asıksoy (2018) reported that Turkish undergraduates believe strongly that Web 2.0 tools help them in English learning and perceived ease of use and perceived usefulness of Facebook in language learning process were at a high level.

The findings on the effectiveness of Web 2.0 in language learning process in relation to genders are consistent with previous research. It was found in this study that females had more perceived usefulness than males. This finding is coherent with that by NingShen and Khalifa (2010) who showed that females outperformed males in using Facebook for English language learning. Also, Cuadrado-Garcíaet, Ruiz-Molina, and Montoro-Pons (2010) suggested that women are more involved in using computers and social media in communicative activities. Partially similar to the finding of this study, Duggan and Brenner (2012) found a slightly higher female participation in Web 2.0, and in particular social media sites. Similarly, Adamus, Kerres, Getto, and Engelhardt, (2009) found that females used more Web 2.0 applications for learning. As for the variable of level of the study in relation to language learning effectiveness, it was reported that significant differences existed between master and $\mathrm{PhD}$ graduates in favor of master students in English language learning effectiveness using Web 2.0. This finding is line with that by Smith, Salaway, and Caruso (2009) who found that no statistically significant difference between the fresh and senior students.

However, more perceived usefulness by female participants reported in this study is inconsistent with $\mathrm{Wu}$, et al. (2010) who stated that males were more self-confident and more skilled in using Web 2.0 technologies like Wikis. Also, Alajmi (2011) found no significant difference in learners' readiness towards using Web 2.0 in language learning between both groups. In addition, Blau and Caspi (2010) reported no significant differences between males and females in using Google applications for learning. Moreover, Wei, Fielden, and Joyce (2013) indicated that there were only very minor differences between the ways that male and female postgraduate students use Web 2.0 applications.

YouTube, Facebook, and Skype for learning English language were the most preferred Web 2.0 tools in English language learning reported in this study. This finding agrees with Asıksoy (2018) who found that YouTube, Social networking, and blogs were the most used tools by Turkish undergraduates. Also, Alshabebe and Almaqrn (2018) revealed that university students use social media such as Twitter/Instagram/ Facebook 
in discovering and looking for new vocabulary and communicating in English. In addition, Kabooha and Elyas (2018) reported that learners found YouTube as a helping tool to improve their English vocabulary. Nevertheless, the finding is slightly different from the outcomes of Alajmi (2011) who revealed that 'YouTube' and MSN Messenger were the top two Web 2.0 tools for English language learning. Alajmi (2011) also found that, Facebook and Wikipedia had a rate somewhere between "novice" and "competent."

\section{RECOMMENDATIONS}

Based on the findings of this study, it is recommended that training on Internet and integration skills be proved to learners of a new language to allow them more reliable resources into their learning process. Also, more focused research on only one Web 2.0 tools like Facebook or Twitter in learning English language may yield more profound findings. Most importantly, further research about the practice and attitudes of educators in using Web 2.0 technologies for teaching English Language will seem more beneficial, as they appear to be the other side of the whole process.

\section{LIMITATIONS OF THE STUDY}

This study was only confined to Arab postgraduate students studying in UKM in Malaysia. Also, the language targeted in this study is limited to English language. In addition, a small number of sample size was examined in this study. Therefore, the generalization of the study findings should only be restricted to the population described in the study and of which the sample was extracted. In future, the numbers of participants could be increased and students from EFL majors have to be selected as the main respondents.

\section{CONCLUSION}

The study examined how the Arab postgraduate students studying in UKM are ready to utilizing Web 2.0 in their language learning process. The students' perceived usefulness towards utilization and effectiveness of using Web 2.0 in English language process was moderate. YouTube, Facebook, and Skype were mostly preferred by Arab postgraduate students for learning English language. Females had more perceived usefulness and see Web 2.0 applications are effective in learning English language as against their male counterparts. Finally, master's students had more perceived usefulness think that Web 2.0 tools are effective in English language learning more than $\mathrm{PhD}$ students. The findings of this study may complete the full agenda of Web 2.0 technologies adoption by Arab postgraduate learners studying in UKM. The second point, this study functions to lend support to literature by contributing significantly to it because of its emphasis on the characteristics of innovations that have an impact on the academic students in embracing technologies in their learning process. In addition, this study recognizes the shortcomings which impede academic students from using Web 2.0 technologies in a broader way, as a new innovation, thereby facilitating educational policy makers to assess the electronic media and wade through the obstacles. Last but not least, this study is also expected to shed the light on the use of technologies in language learning process that eventually can be used as the doors for other researchers who are interested in conducting research in the same or similar area. 


\section{REFERENCES}

Abbitt, J.T. (2009). Evaluating the implementation of a social bookmarking activity for an undergraduate course. Journal of Interactive Online Learning, 8(1), 83-101.

Adamus, T., Kerres, M., Getto, B., \& Engelhardt, N. (2009, March). Gender and etutoring-A concept for gender sensitive e-tutor training programs. In 5th European symposium on gender and ICT digital cultures: Participation-Empowerment-Diversity (pp. 5-7). https://doi.org/10.2307/j.ctvdf061g.18

Alajmi, M. (2013). Modeling student perception of Web 2.0 technologies adoption in Kuwait. Unpublished doctoral dissertation, University of North Texas, Denton, TX.

Alexander, B. (2006). Web 2.0: A new wave of innovation for teaching and learning?. EDUCAUSE Review, 41(2), 32-44.

Al-hawari, M., Meloche, J. \& Al-halabi, S. (2009). A Preliminary Investigation of the Factors that Influence the Elearning Adoption in Higher Education Institutes in emerging societies. In T. Bastiaens et al. (Eds.), Proceedings of World Conference on E-Learning in Corporate, Government, Healthcare, and Higher Education 2009 (pp. 2345-2352). Chesapeake, VA: AACE. Retrieved from http://www.editlib.org/p/32811 https://doi.org/10.4018/jdet.2010100101

Al-Khalifa, H. S. (2010). Finding a Place for Twitter in Higher Education. eLearn, 2010(5), $6 . \quad$ Retrieved from https://elearnmag.acm.org/archive.cfm?aid=1821980\&doi=10.1145\%2F1795374.18219 80 http://doi.acm.org/10.1145/1795374.182198

Allehaibi, M. M. (2001). Faculty adoption of Internet technology in Saudi Arabian universities. Unpublished doctoral dissertation, Florida State University.

Almekhlafy, A., \& Alzubi, A. A. F. (2016). Mobile-mediated communication a tool for language exposure in EFL informal learning settings. Arab World English Journal, 7(1), 388- 407.https://doi.org/10.2139/ssrn.2804018

Al-Oteawi, S. M. (2002). The perceptions of administrators and teachers in utilizing information technology in instruction, administrative work, technology planning and staff development in Saudi Arabia (pp. 1-373). Ohio University.

Al Shabab, A. \& Almaqrn, R. (2018). A study of EFL Saudi students' use of mobile social media applications for learning. Arab World English Journal, Special Issue on CALL No. 8, 214-226. https://doi.org/10.2139/ssrn.3226723

Al Shlowiy, A. S. (2016). Promoting EFL learning outside the classroom through the use of web-based technologies after the adoption of Blackboard in a Saudi University. Doctoral Dissertation, University of New Mexico.

Al-Wehaibi, K., Al-Wabil, A., Alshawi, A. \& Alshankity, Z. (2008). Barriers to Internet Adoption among Faculty in Saudi Arabian Universities. In J. Luca \& E. Weippl (Eds.), Proceedings of World Conference on Educational Multimedia, Hypermedia and Telecommunications 2008 (pp. 24-33). Chesapeake, VA: AACE. Retrieved from http://www.editlib.org/p/28372 
Anderson, P. (2007). What is Web 2.0? Ideas, technologies and implications for education. JISC Technology and Standards Watch, 1-64. Retrieved from www.jisc.ac.uk/media/documents/techwatch/tsw0701b.pdf

Arshad, A., Tan B.H., \& Hashim, A. (2012). Tertiary Students' Application of Web 2.0 for English Language Learning. Malaysian Journal of ELT Research, 8(2), 21-37.

Aş1ksoy, G. (2018). ELT students' attitudes and awareness towards the use of WEB 2.0 technologies for language learning. Journal of Language and Linguistic Studies, 14(2), 240-251.

Aydin, S. (2017). A Descriptive Study on EFL Learners' Perceptions of Facebook. Atatürk Üniversitesi Sosyal Bilimler Enstitüsü Dergisi, 21(2), 381-400.

Ayres, R. (2002). Learner attitudes towards the use of CALL. Computer Assisted Language Learning, 15, 241-249. https://doi.org/10.1076/call.15.3.241.8189

Bell, A. (2009). Exploring web 2.0: second generation internet tools-blogs, podcasts, wikis, networking, virtual worlds, and more. Georgetown, TX: Katy Crossing Press

Blau, I., \& Caspi, A. (2009). What type of collaboration helps? Psychological ownership, perceived learning and outcome quality of collaboration using Google Docs. In Proceedings of the Chais conference on instructional technologies research (Vol. 12, No. 1, pp. 48-55).

Burhanna, K., Seeholzer, J., \& Salem, Jr., J. (2009). No natives here: A focus group study of students perceptions of Web 2.0 and the academic library. The Journal of Academic Librarianship, 35(6), 523-532. https://doi.org/10.1016/j.acalib.2009.08.003

Campbell, A. P. (2004). Using LiveJournal for authentic communication in EFL classes. The Internet TESL Journal, 10(9), 64-68.

Canning-Wilson, C., \& Wallace, J. (2000). Practical aspects of using video in the foreign language classroom. The Internet TESL Journal, 6(11), 36-1.

Cardine, S. (2008). Is education ready for YouTube. Center for Digital Education/Converge, 9, 10-13.

Chao, Y., \& Lo, H. (2009). Students' perceptions of Wiki-based collaborative writing for learners of English as a foreign language. Interactive Learning Environments, 19(4), 395-411. https://doi.org/10.1080/10494820903298662

Collis, B., \& Mooned, J. (2008). Web 2.0 tools and processes in higher education: Quality perspectives. Educational Media International, 45(2), 93-106. https://doi.org/10.1080/09523980802107179

Coutinbo, C., \& Junior, J., B., (2008). Using social bookmarking to enhance cooperation / collaboration in a teacher education program. In Proceedings of World Conference on Educational Multimedia, Hypermedia and Telecommunications 2008 (pp. 2551-2556). Chesapeake, VA: AACE.

Creswell, J. W. (1994). Research Design: Qualitative and Quantitative Approaches. Thousand Oaks. CA: Sage. 
Cuadrado-García, M., Ruiz-Molina, M. E., \& Montoro-Pons, J. D. (2010). Are there gender differences in e-learning use and assessment? Evidence from an interuniversity online project in Europe. Procedia Social and Behavioral Sciences 2, 367-371. https://doi.org/10.1016/j.sbspro.2010.03.027

Cundell, A. (2008). The integration of effective technologies for language learning and teaching. In P. Davidson, J. Shewell, \& W.J. Moore (Eds.), Educational Technology in the Arabian Gulf: Theory, research and pedagogy (pp. 13-24). Dubai: TESOL Arabia

Davis, F. D., Bagozzi, R. P., Warshaw, P. R. (1989). User acceptance of computer technology: A comparison of two theoretical models. Management Science, 35 (8), 982-1003. https://doi.org/10.1287/mnsc.35.8.982

Ducate, L., \& Lomicka, L. (2009). Podcasting: An effective tool for honing language students' pronunciation? Language Learning \& Technology, 13(3), 66-86.

Ducate, L., Anderson, L., \& Moreno, N. (2011). Wading through the world of wikis: An analysis of three wiki projects. Foreign Language Annals, 44(3), 495-524. https://doi.org/10.1111/j.1944-9720.2011.01144.x

Duggan, M. \& Brenner, J. (2012). The demographics of social media users. Educational Technology \& Society, 12(2), 11-21.

Elola, I., \& Oskoz, A. (2010). Collaborative writing: Fostering foreign language and writing conventions development. Language Learning \& Technology, 14(3), 51-71.

Eneau, J., \&Develotte, C. (2012).Working together online to enhance learner autonomy: Analysis of learners' perceptions of their online learning experience.ReCALL, 24(1), 3 19. https://doi.org/10.1017/s0958344011000267

Franklin, T., \& Van Harmelen, M. (2007). Web 2.0 for content for Learning and Teaching in Higher Education. Bristol: JISC.

Gilakjani, A. (2017). A Review of the Literature on the Integration of Technology into the Learning and Teaching of English Language Skills. International Journal of English Linguistics, 7(5), 95-106. https://doi.org/10.5539/ijel.v7n5p95

Godwin-Jones, R. (2006). Tag clouds in the blogosphere. Language Learning \& Technologies, 10(2), 8-15.

Grosseck, G. (2009). To use or not to use web 2.0 in higher education? Proceedings of the World Conference on Educational Sciences, 1(1), 478-482. https://doi.org/10.1016/j.sbspro.2009.01.08

Henzinger, M.R., Motwani, R., \& Silverstein, C. (2002). Challenges in web search engines. ACM SIGIR Forum, 36(2), 11-22. https://doi.org/10.1145/792550.792553

Johnson, A. (2004). Creating a writing course utilizing class and student blogs. The internet TESL journal, 10(8), 1-10.

Kabooha, R. H. (2016). Using Movies in EFL Classrooms: A Study Conducted at the English Language Institute (ELI), King AbdulAziz University. English Language Teaching, 9(3), 248-267. https://doi.org/10.5539/elt.v9n3p248 
Kabooha, R., \& Elyas, T. (2018). The Effects of YouTube in Multimedia Instruction for Vocabulary Learning: Perceptions of EFL Students and Teachers. English Language Teaching, 11(2), 72-81. https://doi.org/10.5539/elt.v11n2p72

Kitchakarn, O. (2016). How Students Perceived Social Media as a Learning Tool in Enhancing Their Language Learning Performance. Turkish Online Journal of Educational Technology-TOJET, 15(4), 53-60.

Kleanthous, A., \& Cardoso, W. (2016). Collaboration through blogging: the development of writing and speaking skills in ESP courses. EUROCALL, 225-230. https://doi.org/10.21125/edulearn.2016.1230

Kost, C. (2011). Investigating writing strategies and revision behavior in collaborative wiki projects. CALICO Journal, 28(3), 606-620. https://doi.org/10.11139/cj.28.3.606-620.

Kung, F. W. (2018). Assessing an innovative advanced academic writing course through blog-assisted language learning: Issues and resolutions. Innovations in Education and Teaching International, 55(3), 348-356. https://doi.org/10.1080/14703297.2015.11082

Lee, L. (2005). Using web-based instruction to promote active learning: Learners' Perspectives.CALICO Journal, 23, 139-156. https://doi.org/10.1558/cj.v23i1.139-156

Lee, L. (2010). Exploring wiki-mediated collaborative writing: a case study in an elementary Spanish course. CALICO Journal, 27(2), 260-276. https://doi.org/10.11139/cj.27.2.260-276

Lee, L. (2009). Promoting intercultural exchanges with blogs and podcasting: A study of Spanish-American telecollaboration. Computer Assisted Language Learning, 22(5), 425-443. https://doi.org/10.1080/09588220903345184

Leuf, B., \& Cunningham, W. (2001). The wiki way: Quick collaboration on the web. Upper Saddle River, New Jersey: Addison-Wesley.

Li, M., \& Zhu, W. (2013). Patterns of computer-mediated interaction in small writing groups using wikis. Computer Assisted Language Learning, 26(1), 61-82.

Lin, W., \& Yang, S. (2011). Exploring students' perceptions of integrating wiki technology and peer feedback into English writing courses. English Teaching: Practice and Critique, 10 (2), 88-103.

Lundin, R. W. (2008). Teaching with wikis: Toward a networked pedagogy. Computers and Composition, 25, 432-448. https://doi.org/10.1016/j.compcom.2008.06.001

Ning Shen, K., \& Khalifa.,M. (2010). Facebook usage among Arabic college students: Preliminary findings on gender differences. Proceedings of the 9th International Conference on Electronic Business (pp.1080 -1087), Macao, P. R. China. https://doi.org/10.3316/ijebm0401053

Najeeb, Z. M., Maros, M., \& Nor, N. F. M. (2012). Politeness in e-mails of Arab students in Malaysia. GEMA Online ${ }^{\circledR}$ Journal of Language Studies, 12(1), 125-145.

O'Reilly, T., \& Dougherty, D. (2004). O'Reilly Media Web 2.0 Conference.https://en.wikipedia.org/wiki/Web_2.0 
Ormond, P.R. (2008). Podcasting enhances learning. Journal of Computing Sciences in College, 24(1), 232-238.

Paul, J. Z., \& Friginal, E. (2019). The effects of symmetric and asymmetric social networks on second language communication. Computer Assisted Language Learning, 1-32. https://doi.org/10.1080/09588221.2018.1527364

Rosen, A., (2006). Technology Trends: e-learning 2.0. The eLearning Guide, 1-7. Retrieved from http://www.readygo.com/e-learning-2.0.pdf

Shihab, M.M. (2008). Web 2.0 tools improve teaching and collaboration in English language classes. International College, Beirut, Lebanon.

Shyamlee, S. D., \& Phil, M. (2012). Use of technology in English language teaching and learning: An analysis. In International Conference on Language, Medias and Culture, $33,150-156$.

Smith, S., Salaway, G., Caruso, J. (2009). The ECAR study of undergraduate students and information technology. The EDUCAUSE Center for Applied Research, 1-15. Retrieved from http://www.csplacement.com/downloads/ECAR-ITSkliisstudy.pdf

Taskiran, A., Gumusoglu, E. K., \& Aydin, B. (2018). Fostering Foreign Language Learning with Twitter: What Do English Learners Think About It?. Turkish Online Journal of Distance Education, 19(1), 100-116. https://doi.org/10.17718/tojde.382734

Vandewaetere, M., \& Desmet, P. (2009). Introducing psychometrical validation of questionnaires in CALL research: The case of measuring attitude towards CALL. Computer Assisted Language Learning, 22(4), 349-380.

Viswanathan, R. (2008). Using mobile technology and podcasts to teach soft skills. In M. Thomas (Ed.), Handbook of research on Web 2.0 and second language learning, pp. 223-.236. PA: IGI Global. https://doi.org/10.4018/978-1-60566-190-2.ch012

Wei, N., Fielden, K. \& Joyce, D. (2013). Web 2.0 usage among New Zealand learners: Findings on gender difference.Journal of Applied Computing and Information Technology, 17(1), 1-8 .

Woo, M., Chu, S., Ho, A., \& Li, X. (2011). Using a wiki to scaffold primary-school students' collaborative writing. Educational Technology \& Society, 14(1), 43-54.

Wu, H.Y., Hsu, H.P., Teng, S.C., \& Wu, H.C. (2010). How do demographic variables relate to attitudes on English reading and writing when using a Web 2.0 tool? Proceedings of the 4th International Conference on e-Learning (pp. 501 -508), Penang, Malaysia.

Zakaria, M. H., Watson, J., \& Edwards, S. (2010). Investigating the use of Web 2.0 technology by Malaysian students. Multicultural Education \& Technology Journal, 40(1), 17-29. https://doi.org/10.1108/17504971011034700

Zorko, V. (2009). Factors affecting the way students collaborate in a wiki for English language learning. Australasian Journal of Educational Technology, 25(5), 645-665. https://doi.org/10.1108/17504971011034700 